\title{
Situs Sangiran : Potensi Dan Permasalahan Dalam Pengembangan Dan Pemanfaatannya
}

\section{Muhammad Hidayat}

Keywords: cultural resource management, conservation, spatial, protection, prehistoric site, heritage

\section{How to Cite:}

Hidayat, M. (2003). Situs Sangiran : Potensi Dan Permasalahan Dalam Pengembangan Dan Pemanfaatannya. Berkala Arkeologi, 23(2), 114-126. https://doi.org/10.30883/jba.v23i2.880

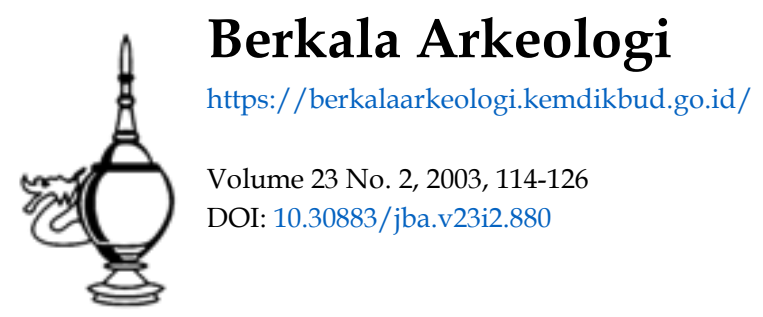

\section{c) (†) (-)}

This work is licensed under a Creative Commons Attribution-NonCommercial-ShareAlike 4.0 International License. 


\section{SITUS SANGIRAN : POTENSI DAN PERMASALAHAN \\ DALAM PENGEMBANGAN DAN PEMANFAATANNYA}

\section{Muhammad Hidayat}

\section{$\mathbf{P}$}

endahuluan

Situs arkeologi sebenarnya merupakan salah satu asset daerah. Terhadap situs dapat digali potensinya untuk kepentingan pembangunan secara luas sesuai dengan kekuatan dan jenis potensi yang dikandungnya. Namun masih banyak situs yang belum menarik minat Pemerintah Daerah setempat untuk mengelolanya, apalagi mengembangkan untuk pemanfaatan secara maksimal. Hal ini dapat disebabkan oleh beberapa faktor, di antaranya adalah belum dimilikinya SDM yang dapat mengelola (secara tepat dan benar), ataupun terabaikan karena adanya sumberdaya lain yang dipandang lebih berpotensi dari segi lain, misal ekonomi.

Akibat diterapkannya otonomi daerah, banyak situs-situs arkeologi dengan kandungan yang menarik diarahkan pemanfaatannya untuk kepentingan ekonomi, yaitu sebagai salah satu sumber Pendapatan Anggaran Daerah (PAD) dengan menjadikannya sebagai obyek wisata. Pengelolaan yang salah maupun pemaksaan pemanfaatan yang tidak sesuai dengan potensinya akan dapat merugikan kelestarian situs maupun pengelola itu sendiri yang telah menanamkan modalya. Situs arkeologi merupakan salah satu kawasan lindung yang harus dijaga kelestariannya. Oleh karena itu dalam pemanfaatan situs arkeologi harus benar-benar mengacu pada kelestarian situs tersebut. Selain itu, untuk menjadikannya sebagai obyek wisata harus didukung oleh penunjang lainnya seperti prasarana, sarana, maupun lokasinya.

Sangiran, merupakan salah satu situs arkeologi yang sangat terkenal di Indonesia maupun di dunia. Nilai yang terkandung pada situs yang berskala internasional ini tidak diragukan lagi. Mengingat akan nilainya ini, Pemerintah Pusat melakukan pengelolaan yang terkait dengan penelitian dan pelestarian situs melalui UPT nya yang ada di daerah. Dan sadar akan potensinya pula yang ada pada Situs Sangiran, Pemerintah Daerah Kabupaten Sragen telah berupaya pula memanfaatkan asset tersebut untuk kepentingan pembangunan daerah, yaitu sebagai obyek wisata maupun pendidikan. Pemanfaatan dan pengembangan Situs Sangiran tidak luput dari permasalahan, khususnya yang menyangkut peraturan kelestarian situs. Berikut adalah gambaran potensi dan permasalahan dalam pemanfaatan dan pengembangan pada Situs Sangiran yang dikelola oleh Pemerintah Kabupaten Sragen. 


\section{$\mathbf{P}$}

otensi Akademik Situs Sangiran

Sangiran adalah nama sebuah dusun di wilayah Desa Krikilan, Kecamatan Kalijambe, Kabupaten Sragen. Nama Sangiran ini kemudian digunakan pula untuk menyebut dome yang merupakan situs yang sangat luas dan mencakup dusun tersebut. Luas keseluruhan situs yang disebut sebagai Situs Sangiran paling tidak 56 $\mathrm{km}^{2}$, yang berada di wilayah Kabupaten Sragen (Kecamatan Kalijambe, Gemolong, dan Plupuh) serta Kabupaten Karanganyar (Kecamatan Gondangrejo).

Situs Sangiran mulai dikenal sejak ditemukan alat-alat batu berupa serpih bilah di Desa Ngebung oleh von Koenigswald pada tahun 1934 dan fosil hominid pada tahun 1936 (Harry Widianto, 1994). Dan sejak itu berulang kali telah dilakukan penelitian hingga akhir-akhir ini baik mengenai manusia, budaya, maupun lingkungannya yang mencakup fauna dan geologinya. Walaupun telah puluhan dan mungkin ratusan kali telah dilakukan penelitian, namun permasalahan akademik dan informasi baru yang didapatkan tiada habis-habisnya.

Pada Situs Sangiran terkandung sisa-sisa kehidupan masa purba, jutaan tahun hingga ratusan ribu tahun yang lalu. Hingga saat ini, di situs tersebut telah ditemukan fosilfosil hominid dan budayanya, maupun binatang yang hidup pada masa itu, khususnya pada kala Plestosen. Sisa hominid yang ditemukan mencapai lebih dari 50 individu. Jumlah ini mewakili sekitar $65 \%$ dari seluruh fosil hominid yang ditemukan di Indonesia, dan merupakan $50 \%$ dari populasi Homo erectus yang sisa-sisanya pernah di temukan di dunia. Keberadaan fosil Homo erectus yang demikian banyak ini menjadikan situs ini dianggap sebagai salah satu pusat evolusi manusia di dunia, dan telah dipakai sebagai tolok ukur untuk mengkaji proses-proses evolusi secara umum (Harry Widianto, 1994).

Ribuan artefak batu dari berbagai tipe dan jenis bahan yang ditemukan tersebar di permukaan tanah maupun dalam kegiatan ekskavasi di Situs Sangiran diyakini sebagai hasil budaya Homo erectus. Secara umum tipe artefak yang ditemukan di Situs Sangiran berupa kapak perimbas, kapak penetak, bola batu, serut, dan alat serpih bilah. Jenis batu yang digunakan sebagai bahan alat-alat yang berfungsi teknis tersebut di antaranya berupa kalsedon, kuarsa, jaspis, maupun andesit. Hingga saat ini diyakini bahwa budaya alat batu paleolitik yang pernah berkembang di Indonesia yang tertua ditemukan di Situs Sangiran. Di situs ini ditemukan bukti bahwa alat batu telah berkembang paling tidak sejak 800.000 tahun yang lalu, dan masih berkembang hingga 180.000 tahun yang lalu.

Berbagai jenis fosil binatang yang ditemukan di Situs Sangiran berasal dari vertebrata, baik yang hidup di lingkungan darat maupun air. Fosil binatang darat yang ditemukan di antaranya berasal dari jenis gajah (Stegodon sp. dan Elephantidae), rusa, babi, banteng, kerbau, harimau, badak, dan ayam hutan. Sementara binatang air di 
antaranya berasal dari jenis kura-kura, ikan, buaya, dan kuda nil (Harry Widianto, 1997; 1998). Di Jawa khususnya, dan pada umumnya di wilayah Indonesia, beberapa jenis binatang tersebut pada saat ini telah punah, dan beberapa di antaranya telah mengalamai reduksi fisik (evolusi).

Selain berbagai jenis fosil dan artefak batu yang ditemukan di Situs Sangiran, pada situs ini terdapat pula singkapan-singkapan yang menunjukkan stratigrafi endapan yang sangat tebal dan terbentuk dalam masa yang sangat panjang. Pada beberapa lapisan, merupakan lapisan pengandung fosil dan artefak. Berdasarkan singkapan yang lengkap dapat diketahui bahwa di situs tersebut terdapat 5 lapisan yaitu Formasi Kalibeng, Formasi Pucangan, grenzbank, Formasi Kabuh, dan Formasi Notopuro.

Menilik pada kandungannya, Situs Sangiran mempunyai potensi yang luar biasa bagi pengembangan ilmu pengetahuan dan informasi. Bidang ilmu yang dapat dikembangkan dari situs tersebut terutama mengenai evolusi manusia, evolusi budaya paleolitik, evolusi vertebrata, paleoekologi, serta geologi yang menyangkut sejarah terbentuknya lahan di lingkungan Situs Sangiran dan Pulau Jawa bagian timur pada umumnya.

Terhadap potensi yang dimiliki Situs Sangiran ini telah diakui pula oleh dunia, sehingga Situs Sangiran Situs telah ditetapkan sebagai warisan dunia oleh UNESCO. Sebagai dasar penetapan Situs Sangiran sebagai warisan dunia adalah penilaian ICOMOS terhadap potensi situs tersebut seperti berkut (Harry Widianto, dkk. 1996):

- Situs Sangiran merupakan situs manusia purba yang mempunyai nilai dunia. Situs ini menunjukkan berbagai aspek evolusi fisik dan budaya manusia dalam konteks natural, dalam suatu periode yang panjang. Situs Sangiran akan selalu menjadi sumber informasi tentang evolusi manusia purba.

- Situs Sangiran merupakan salah satu situs kunci untuk pemahaman evolusi manusia. Melalui fosil-fosil (manusia, binatang) dan alat-alat paleolitik yang ditemukan di Sangiran, situs ini menggambarkan evolusi Homo sapiens sejak Kala Plestosen Bayah hingga saat ini.

\section{$\mathbf{P}$}

\section{otensi Situs Sangiran sebagai Obyek Wisata} A. Setting Geografis

Situs Sangiran berada pada sebuah kubah (dome) yang disebut sebagai Kubah Sangiran yang telah terkikis oleh Sungai Cemoro serta sungai-sungai kecil yang merupakan anak-anak Sungai Cemoro tersebut di bagian tengah kubah. Akibat adanya kikisan sungai dan struktur geologi yang pada umumnya labil dan mudah longsor menjadikan relief situs tidak rata, di bagian tengah menjadi rendah sedang di bagian pinggir (keliling) tinggi. Secara keseluruhan menjadikan relief Situs Sangiran seperti perbukitan kecil dan rendah, ada bagian lembah, lereng, dan puncak. 
Pada musim penghujan areal Situs Sangiran tampak menghijau. Pada musim ini pula aktivitas petani sederhana yang mendiami areal situs banyak melakukan aktivitas pertanian. Sementara pada musim kemarau, sebagian besar areal Situs Sangiran tampak gersang.

\section{B. Pengelolaan Lingkungan}

Usaha pelestarian terhadap Situs Sangiran hingga kini terus ditangani secara serius khususnya oleh yang berwenang, dalam hal ini adalah dari Balai Pelestarian Peninggalan Purbakala (BP3) Propinsi Jawa Tengah. Bentuk pengelolaan yang dilakukan berupa pendirian "museum" untuk pengumpulan dan perawatan fosil yang ditemukan (oleh penduduk), penyuluhan kepada masyarakat di lingkungan situs, maupun pengawasan terhadap situs tersebut.

Perhatian terhadap kelestarian situs telah pula diberikan oleh aparat Pemerintah Daerah setempat, yaitu pelarangan terhadap penambangan pasir maupun sedimen yang lain di areal situs. Selain itu dalam usahanya menjaga kelestarian situs, Pemda juga telah berupaya membina masyarakat setempat, khususnya pengrajin souvenir untuk mengalihkan bahan baku souvenir dari bahan fosil ke bahan lainnya, seperti kayu, batu maupun tulang.

Terkait dengan pengelolaan situs, pihak Pemda Kabupaten Sragen, Pemda Tk. I, maupun Pemerintah Pusat lewat BP3 telah menyusun perencanaan (dan sebagian telah dijalankan) untuk pelestarian serta pemanfaatan dan pengembangan Situs Sangiran, khususnya pada museum. Pada saat ini telah mulai dilakukan peningkatan SDM pengelola (penambahan tenaga), penambahan fasilitas kerja, dan penambahan ruang pamer museum. Selain itu Pemerintah Pusat lewat Pusat Penelitian Arkeologi maupun Balai Arkeologi Yogyakarta juga telah berulang kali melakukan penelitian untuk menggali informasi sejarah budaya pada situs tersebut.

\section{Keragaman Atraksi}

Situs Sangiran merupakan situs paleoantropologi, arkeologi, dan paleontologi yang sangat lengkap di Indonesia, bahkan di dunia. Seperti diketahui bahwa di situs ini telah ditemukan sekitar $65 \%$ dari seluruh fosil Homo erectus yang ditemukan di Indonesia, dan $50 \%$ yang ditemukan di seluruh dunia. Selain itu ditemukan pula artefak batu yang diyakini sebagai hasil budaya mereka dari 800.000 hingga 180.000 tahun yang lalu. Dan hingga saat ini di situs ini masih terus ditemukan fosil-fosil vertebrata yang sebagian diantaranya telah punah dari wilayah Indonesia maupun telah mengalami evolusi. Keberadaan fosil manusia purba, artefak, binatang menunjukkan adanya kehidupan pada masa prasejarah di lingkungan itu. Dan adanya 
perbedaan fisik pada beberapa fosil manusia maupun binatang menunjukkan pula adanya proses evolusi yang terjadi di lingkungan tersebut.

Di Situs Sangiran terdapat sebuah museum yang berfungsi sebagai tempat penyimpanan, perawatan, dan pameran terhadap fosil dan artefak yang ditemukan di situs tersebut. Dengan adanya museum ini maka fosil dan artefak yang ditemukan akan terjaga kelestariannya. Dan keberadaan museum ini dapat dimanfaaatkan oleh masyarakat luas baik untuk menambah ilmu pengetahuan, penelitian, pendidikan, maupun rekreasi.

Situs Sangiran merupakan situs yang terbuka dan sangat luas (lebih dari $56 \mathrm{~km}^{2}$ ). Relief permukaan situs tidak rata dan menyerupai relief perbukitan. Areal situs menghijau pada musim penghujan dan terasa gersang serta panas pada musim kemarau. Keadaan alam yang demikian ini merupakan tantangan tersendiri bagi sebagian orang yang suka berpetualang. Di atas lahan situs tedapat beberapa kelompok permukiman (desa) dengan rumah-rumah tradisional berarsitektur Jawa Tengah. Pada umumnya rumah yang masih "asli" berdinding kayu dan beratap limasan. Pada bubungan biasanya terdapat hiasan tokoh wayang maupun binatang (ayam) dari bahan seng maupun terakota. Rumah-rumah tradisional semacam itu tidak banyak lagi ditemukan di desa-desa di Jawa Tengah.

Sebagian masyarakat di lingkungan Situs Sangiran, khususnya di wilayah Kecamatan Kalijambe masih melestarikan kesenian tradisional Jawa yaitu seni karawitan, maupun kesenian tradisional yang bernafaskan Islam seperti seni rodat (rebana). Selain itu terdapat pula kelompok kesenian yang tergolong seni kontemporer yaitu ndangdut dan campursari. Walaupun masih cukup banyak kelompok-kelompok kesenian tradisional seperti yang terdapat di wilayah Kalijambe tersebut, namun ada kecenderungan penurunan pelestari kesenian tradisional serta kurang mendapat kesempatan tampil/pentas khususnya di lingkungan perkotaan. Dan akhimya kesenian semacam itu bagi masyarakat kota di Jawa dan terlebih luar Jawa dan luar negeri dapat menjadikan sebuah atraksi yang cukup menarik.

Meskipun masih tergolong kecil (tradisional) di lingkungan Situs Sangiran terdapat beberapa pengrajin batu cincin serta souvenir lainnya dari bahan batu dan tulang. Selain itu terdapat pula beberapa pengrajin meubel (furniture), dan tidak jauh dari Sangiran namun di luar lingkungan situs (di Plupuh) terdapat pula pengrajin batik. Khususnya souvenir produk pengrajin dari lingkungan Situs Sangiran ini mempunyai ke khasan tersendiri dan tidak ditemukan di luar Sangiran. 


\section{Hubungan Antar Obyek}

Tidak begitu jauh dari lokasi Situs Sangiran dan masih dalam satu jalur utama Solo Purwodadi, terdapat 2 buah obyek wisata yang berlainan jenisnya. Kedua obyek ini juga berada di wilayah Kabupaten Sragen, yaitu di Gunung Kemukus dan Waduk Kedung Ombo.

Di Gunung Kemukus terdapat makam Pangeran Samodra yang menurut legenda merupakan putra raja Majapahit terakhir yang diangkat oleh Raja Demak pertama, yaitu Raden Patah. Pada saat sedang menjalankan perintah Raden Patah untuk mengumpulkan saudara-saudaranya yang terpisah ketika Majapahit runtuh, Pangeran Samodra meninggal karena sakit dan dimakamkan di Gunung Kemukus. Pada Gunung Kemukus ini telah berkembang menjadi wisata ziarah. Pada hari-hari tertentu seperti pada hari Kamis Pahing malam di bulan Muharam, di lokasi tersebut banyak di kunjungi peziarah.

Waduk Kedung Ombo yang merupakan waduk buatan yang ditujukan untuk kepentingan irigasi telah dikembangkan dan dimanfaatkan pula sebagai obyek wisata. Di obyek ini terdapat budidaya ikan dalam karamba, arena pemancingan, dan dilengkapi dengan sarana perahu motor. Selain itu juga terdapat arena camping.

\section{E. Aksesibilitas}

Situs Sangiran dari kota Solo (terminal bus) berjarak sekitar $18 \mathrm{~km}^{2}$, dan berada di dekat jalur utama Solo - Purwodadi. Jalan menuju Situs Sangiran (museum) cukup lebar dan beraspal. Untuk mencapai situs dapat dilakukan dengan dengan mudah, dengan kendaraan pribadi maupun kendaraan umum. Kendaraan pribadi (motor, mobil, bus) dapat masuk hingga halaman museum. Sementara pencapaian dengan kendaraan umum dapat dicapai dari arah Solo maupun arah Purwodadi dengan bus jurusan Solo - Purwodadi maupun bus (kecil) jurusan Solo - Gemolong - Sragen, dan kemudian di Kalijambe berganti kendaraan dengan mikrolet yang melewati jalur dekat museum. Frekuensi angkutan umum (bus) yang melalui jalur Solo - Purwodadi dan lewat Kalijambe sangat sering, berkisar 5-10 menit sekali. Namun frekuensi angkutan umum dari Kalijambe ke museum tidak begitu sering. Dan kekurangan ini bagi sebagian orang dapat teratasi oleh adanya tukang-tukang ojek yang mangkal di Kalijambe, yaitu di pinggir jalan menuju situs. Perjalanan ke Situs Sangiran dari Solo dapat ditempuh sekitar 30 menit.

\section{F. Utilitas/Fasilitas}

Di lingkungan Situs Sangiran telah mendapat layanan penerangan dari PLN dengan cukup. Di lingkungan situs tersebut telah terdapat jaringan listrik yang masuk ke 
seluruh pelosok pedesaan, tidak terkecuali ke kompleks bangunan museum. Khususnya di museum yang telah menjadi obyek kunjungan wisata, telah dilengkapi fasilitas umum untuk pengunjung berupa kamar mandi/WC, mushola, dan tempat parkir kendaraan. Walaupun masih sederhana, di seputar (pinggiran) tempat parkir telah terdapat 18 kios cindera mata (souvenir shop), dan 12 kios warung makan/minum namun hanya 2 kios yang rutin buka. Selain itu di luar kompleks museum, yaitu di pinggir jalan menuju museum terdapat pula 8 buah souvenir shop. Secara umum, dengan kondisi jumlah pengunjung saat ini (relatif sedikit), keberadaan utilitas/fasilitas yang telah ada di kompleks museum telah mampu mencukupi kebutuhan pengunjung.

\section{G. Sosial Budaya}

Meskipun berdekatan dengan kota yang cukup besar yaitu Solo, dan akses ke kota tersebut bagus, masyarakat yang tinggal di Situs Sangiran masih bersikap seperti pada umumnya masyarakat pedesaan, ramah dan mempunyai sifat kegotongroyongan yang tinggi. Sikap keramahan tampak jelas terasakan apabila ada orang luar yang masuk ke lingkungan mereka. Masyarakat setempat akan menyapa dan siap memberikan informasi maupun bantuan apabila diperlukan dan mampu dilaksanakan. Mereka juga mau membantu dan berkorban harta bendanya untuk kepentingan bersama dan pembangunan di lingkungannya.

Sebagian besar masyarakat yang berada di lingkungan Situs Sangiran telah menyadari atas kedudukan daerahnya sebagai situs purbakala dan potensi daerahnya untuk kepentingan pembangunan secara luas. Hal ini tampak pada sikap yang positif atas keberadaan museum di lingkungan mereka. Sebagian masyarakat telah sadar dan menyerahkan fosil-fosil yang ditemukannya kepada museum (lihat Bambang Sulistyanto, 1994). Selain itu, khususnya masyarakat yang tinggal di sepanjang jalan menuju meseum telah merelakan sebagian tanahnya untuk kepentingan pelebaran jalan demi mempermudah akses pengunjung ke museum tersebut.

\section{H. Pengunjung}

Pengunjung Situs Sangiran dan museum dalam kondisi saat ini relatif cukup banyak. Selama tahun 2002 terdapat 15.996 pengunjung, yang meliputi wisatawan nusantara maupun asing. Dari sejumlah pengunjung tersebut, 307 di antaranya merupakan wisatawan asing. Asal wisatawan asing yang terbanyak adalah dari negara Jepang (148 orang), Jerman (37 orang), dan Australia (27 orang). Kunjungan terbanyak dari wisatawan Jepang dilakukan antara bulan Mei hingga Oktober, sementara dari Eropa terbanyak dilakukan pada bulan Juli dan Agustus, sedang dari Australia terbanyak dilakukan pada bulan Mei (Statistik Kepariwisataan Kabupaten Sragen Tahun 2002). Sementara pengunjung dalam negeri (wisnus) sebagian besar adalah pelajar SLTP dan 
SLTA. Kunjungan wisatawan nusantara ini terbanyak di lakukan pada bulan Desember (Data Pengunjung dari BP3 Prop. Jateng).

\section{Demanfaatan dan Pengembangan Situs Sangiran \\ A. Kebijakan}

1 Mengingat nilai penting yang terkandung pada Situs Sangiran, selama ini telah banyak dikeluarkan kebijakan-kebijakan yang terkait dengan pengelolaan, baik yang dikeluarkan oleh Pemerintah Pusat, Pemerintah Daerah Propinsi Jawa Tengah, maupun oleh Pemerintah Daerah Kabupaten Sragen. Pengelolaan ini mencakup pada penelitian, pelestarian, serta pengembangan dan pemanfaatannya. Sebagai acuan kebijakan dalam pengelolaan situs di antaranya adalah UU No. 5 Tahun 1992 tentang BCB, UU No. 24 Tahun 1992 tentang Tata Ruang, Kep.Mendagri No. 130-67 Tahun 2002 tentang Pengakuan Kewenangan Kabupaten dan Kota, dan Kewenangan Kabupaten dan Kota Per Bidang dari Departemen/LPND.

Berkaitan dengan kebijakannya, Pemerintah Pusat telah melaksanakan kegiatan di antaranya seperti berikut.

- Menyusun action plan Situs Sangiran dalam jangka pendek hingga jangka panjang (25 tahun)

- Melalui Pusat Penelitian Arkeologi Nasional dan Balai Arkeologi Yogyakarta telah berkali-kali melakukan penelitian untuk menggali informasi akademik maupun mengetahui batas sebaran temuan (fosil dan artefak paleolitik) sebagai bahan revisi batas situs.

- Melalui Direktorat Perlindungan dan Pembinaan Sejarah dan Purbakala (pada waktu itu) mengadakan perencanaan pemintakatan situs

- Melalui Balai Pelestarian Peninggalan Purbakala Prop. Jawa Tengah melakukan pelestarian situs secara rutin dengan pengumpulan, perawatan, dan pameran di kompleks Museum Sangiran, serta melakukan kegiatan penyuluhan kepada masyarakat dan aparat Pemda setempat.

- Membentuk Badan Otorita Sangiran dengan nama Unit Koordinasi Pengelolaan Sangiran. Badan otorita ini terdiri dari unsur Pemerintah Pusat, Pemerintah Propinsi, Pemerintah Kabupaten Sragen, serta para ahli. Pada prinsipnya tugas badan ini adalah melakukan pengelolaan Kawasan Situs Sangiran, termasuk di dalamnya pengembangan, pengawasan, dan pengendalian.

- Melakukan kesepakatan kerjasama dengan Pemda Propinsi Jawa Tengah dan Pemda Kabupaten Sragen dalam pembangunan fisik kompleks Museum Sangiran. Dan pada tahun ini (2003) akan dimulai pelaksanakan pengembangan fisik museum. 
Sementara itu terkait dengan kebijakan pengelolaan Situs Sangiran yang ada di tingkat propinsi, Pemerintah Propinsi Jawa Tengah telah melakukan kegiatan seperti berikut.

- Melalui Dinas Pariwisata Pemda Tingkat I telah melakukan penyusunan Rencana Pengembangan Pariwisata, Rencana Detail Pengembangan Museum, dan Rencana Detail Taman Wisata Purbakala Sangiran

- Melalui Dinas Pekerjaan Umum Cipta Karya Pemda Tingkat I telah melakukan penyusunan Rencana Teknik Ruang Kawasan Sangiran.

Kebijakan yang diambil dalam pengelolaan Situs Sangiran oleh Pemerintah Kabupaten Sragen, di antaranya adalah sebagai berikut.

- Menetapkan Kawasan Situs Sangiran sebagai Kawasan Cagar Budaya, yang dimaksudkan untuk pengembangan ilmu pengetahuan, budaya, arkeologi, serta fungsi rekreasi. Dengan arahan kebijakan pengelolaan: 1). Membebaskan Kawasan Cagar Budaya dari kegiatan budidaya yang mengganggu keamanan benda atau situs purbakala, baik yang sudah ada penampakannya maupun yang sudah diindikasikan; 2). Menetapkan batas kawasan inti dan kawasan penyangga sesuai ketentuan Kantor Suaka Peninggalan Sejarah dan Purbakala, Balai Arkeologi, maupun UNESCO (RTRW Kab. Sragen Th. 2002-2012).

- Mengembangkan Situs Sangiran sebagai obyek wisata dengan mengacu pada rencana yang disusun Pemerintah Propinsi Jawa Tengah. Dan pada saat ini yang telah dilaksanakan di antaranya adalah pembuatan gardu pandang, pelebaran jalan menuju museum, pembangunan/pembenahan utilitas/fasilitas (kamar mandi/WC, mushola), pembinaan pengrajin souvenir, peningkatan sarana kerja dan SDM (pada museum), penyusunan buku panduan untuk pengunjung, pembuatan film kehidupan manusia purba untuk kelengkapan museum, serta pembebasan lahan untuk hutan wisata.

- Menyusun materi pendidikan untuk siswa sekolah dengan memasukkan sejarah budaya yang terkandung pada Situs Sangiran (muatan lokal).

- Membentuk Unit Koordinasi Pengelolaan Kawasan Sangiran Kabupaten Sragen. Unit ini terbatas dari unsur di lingkungan Pemda Kabupaten Sragen.

\section{B. Pengaturan Kelembagaan}

Pengelolaan Situs Sangiran (termasuk museum) sebagai obyek kunjungan utama wisatawan, pada saat ini hanya ditangani oleh pemerintah yaitu oleh Pemerintah Pusat melalui Balai Pelestarian Peninggalan Purbakala (BP3) Propinsi Jawa Tengah yang merupakan UPT Pusat, dan Pemerintah Daerah Kabupaten Sragen. Walaupun secara tegas tidak ada pembagian dalam pengelolaan ini namun tampak terdapat perbedaan dalam penanganannya. Sesuai dengan bidang tugasnya, BP3 melakukan pengelolaan pelestarian situs yang mencakup pengumpulan serta perawatan fosil dan artefak, 
sementara Pemda Kabupaten Sragen menangani pengelolaan yang terkait dengan pengembangan dan pemanfaatannya.

Dalam penanganan pengelolaan selalu dilakukan koordinasi dan kerjasama, yaitu antara BP3 Propinsi Jawa Tengah dengan Pemda Kabupaten Sragen, maupun dengan instansi terkait lainnya seperti Balai Arkeologi Yogyakarta. Di lingkungan Pemda Kabupaten Sragen sendiri dalam hal ini Dinas Perhubungan dan Pariwisata Senibudaya yang menangani pengelolaan, dalam menjalankan tugasnya juga melakukan koordinasi dan kerjasama dengan instansi lain seperti dengan Dinas PU (Kimpraswil), Dinas Pendidikan, Badan Pertanahan, maupun dengan Dinas Perindustrian dan Perdagangan.

Sementara pengelolaan fasilitas penunjang obyek, yaitu souvenir shop dan warung makan yang berada di kompleks museum maupun di sekitar museum dilakukan oleh masyarakat setempat. Khususnya para pedagang souvenir yang berada di kompleks museum telah tergabung dalam wadah koperasi yang mereka bentuk.

\section{Pemasaran}

Dalam usahanya mempromosikan Situs Sangiran, Pemda Sragen telah membuat leaflet. Untuk saat ini leaflet tersebut baru disebarkan pada penguinjung museum, baik wisatawan asing maupun wisatawan nusantara. Direncanakan akan dilakukan pengembangan promosi di antaranya dengan memperluas penyebaran leaflet khususnya ke hotel-hotel, dan pembuatan web site.

$\mathbf{P}$ ermasalahan

Berdasarkan pada hasil studi pemintakatan Situs Sangiran diusulkan bahwa termasuk dalam zona inti adalah areal yang didominasi oleh lapisan lempung hitam Formasi Pucangan, grenzbank, dan Formasi Kabuh; atau dengan Formasi Notopuro termasuk di dalamnya. Sementara termasuk dalam zona penyangga areal yang didominasi Formasi Notopuro di dalam batas wilayah cagar budaya, atau pada Formasi Notopuro dengan radius 100 meter di luar batas wilayah cagar budaya. Sementara termasuk dalam zona pengembangan adalah lahan dengan materi yang didominasi oleh lempung biru Formasi Kalibeng dan lahar Formasi Pucangan (Harry Widianto, 1996).

Seperti diketahui bahwa dalam konsep pelestarian situs dalam zona inti situs harus bebas dari bangunan untuk kepentingan pemanfaatan. Namun dalam pemanfaatan dan pengembangan Situs Sangiran khususnya untuk kepentingan pariwisata ternyata telah melanggar aturan tersebut. Pada zona inti situs (yaitu pada singkapan formasi Notopuro) telah dilakukan pembangunan fasilitas/utilitas berupa menara pandang dan 
ruang parkir. Dari segi pemanfaatan untuk kepentingan pariwisata, pemilihan lahan untuk bangunan gardu pandang ini sangat strategis. Lokasi ini berada pada tempat yang tinggi, dan dari lokasi ini dapat diamati pemandangan berupa relief sebagian besar lahan situs.

Selain itu areal yang termasuk dalam zona pengembangan pada Situs Sangiran terlalu sempit dibanding dengan luas keseluruhan situs yaitu hanya seluas $1,8064 \mathrm{Km}^{2}$ (Harry Widianto, 1996). Zona ini berada di tengah-tengah areal situs. Pada saat ini areal zona pengembangan telah penuh dengan bangunan rumah-rumah penduduk dan museum sehingga sulit untuk dilakukan pengembangan yang terkait dengan pembangunan fasilitas/utilitas untuk kepentingan pariwisata.

$\mathbf{P}$ enutup Pemanfaatan Situs Sangiran sebagai obyek wisata dan pendidikan adalah sangat tepat. Pemanfaatan tersebut telah sesuai dengan potensi yang terkandung pada situs dan lingkungannya, serta mendapat dukungan dari Pemerintah Daerah Tingkat I maupun Pemerintah Pusat. Kekurangan yang tampak pada usaha pemanfaatan dan pengembangan situs tersebut adalah masalah sarana umum pengunjung, khususnya masalah transportasi umum dari Kalijambe menuju situs/museum. Selain itu kekurangan terjadi pula dalam pemahaman mengenai aturan pemanfaatan ruang yang merupakan kawasan cagar budaya, sehingga memunculkan permasalahan pada kelestarian situs.

Permasalahan kelestarian situs seperti yang terjadi dalam pemanfaatan dan pengembangan Situs Sangiran dapat terjadi pada situs-situs arkeologi yang lainnya. Khususnya permasalahan yang muncul di Situs Sangiran, di antaranya disebabkan oleh masalah legalitas pemintakatan situs dan sosialisasi. Hasil studi pemintakatan Situs Sangiran selama ini masih berupa usulan, perlu ditindak lanjuti dengan penetapan secara hukum serta disosialisasikan terutama ke Pemerintah Daerah untuk dijadikan sebagai acuan rambu-rambu dalam pembangunan dan pengembangan di daerah. Permasalahan lain sangat mungkin pula akan muncul terkait dengan pengembangan dan pemanfaatan Situs Sangiran ini sebagai obyek wisata, yaitu munculnya bangunan-bangunan baru. Permasalahan ini perlu diantisipasi dengan peraturan mengenai tata bangunan dan pengontrolan yang ketat.

Seperti telah disebutkan bahwa Situs Sangiran sangat luas (tidak kurang dari $56 \mathrm{Km}^{2}$ ), tentunya hal ini sangat menyulitkan dalam menjaga kelestarian situs secara umum dan keseluruhan. Oleh karena itu perlu dipikirkan kemungkinan penerapan teknik sel dalam pemintakatannya (zoning) pada Situs Sangiran. 


\section{KEPUSTAKAAN}

Undang Undang Nomor 5 Tahun 19992 tentang Benda Cagar Budaya.

Surat Keputusan Mendagri Nomor 130-67 Tahun 2002 tanggal 20 Februari 2002 tentang Pengakuan Kewenangan Kabupaten dan Kota, dan Daftar Kewenangan Kabupaten dan Kota per Bidang dari Departemen/LPND.

Anonim.2002. Laporan Isian Monografi Kecamatan Kalijambe Semester II, Bulan Juli-Desember.

Anonim. 1996. Rencana Pengembangan Cagar Budaya Sangiran. Direktorat Jenderal Kebudayaan.

Anonim. 1996/1997. Rencana Teknik Ruang Kawasan Sangiran. Dinas PU Cipta Karya, Pemerintah Daerah Tk. I Propinsi Jawa Tengah.

Anonim.2003. Statistik Kepariwisataan Kabupaten Sragen Tahun 2002. Dinas Perhubungan dan Pariwisata Senibudaya Kabupaten Sragen.

Anonim.TT. Sragen, Central Java. Dinas Perhubungan dan Pariwisata Senibudaya Kab. Sragen (leaflet).

Anonim.TT. The Most Amazing Things of Sangiran Site, Sragen-Central Java. Sragen Tourism Information Center (leaflet).

Bambang Sulistyanto. 1994. Perilaku Masyarakat Terhadap Benda Cagar Budaya Sangiran: Studi Kasus di Desa Krikilan. Makalah Evaluasi Hasil Studi Teknis Pengembangan Cagar Budaya Sangiran. Surakarta, 4-6 Agustus.

Elfrida Anjarwati. Kehidupan Manusia Purba di Kubah Sangiran. Pemerintah Daerah Kabupaten Sragen, 2003. (Buku panduan pengunjung Museum Sangiran)

Hadi Wahyono, dkk. Rencana Pengembangan Pariwisata Kawasan Sangiran. Dinas Pariwisata Pemerintah Daerah Tingkat I Propinsi Jawa Tengah, Tahun Anggaran 1997/1998.

Harry Widianto. 1994. Situs Sangiran: Posisi dan Potensinya bagi Pemahaman Studi Evolusi Manusia. Makalah Evaluasi Hasil Studi Pengembangan Cagar Budaya Sangiran, Juli. 
Harry Widianto, dkk., 1996. Laporan Hasil Menghadiri Sidang Ke-20 World Heritage Committee di Merida, Mexico, 2-7 Desember 1996. Direktorat Jenderal Kebudayaan, Depdiknas.

dkk. 1997, Penelitian Situs Sangiran: Proses Sedimentasi, Posisi Stratigrafi dan Kronologi Artefak pada Endapan Purba Seri Kabuh dan Notopuro, Berita Penelitian Arkeologi No. 01. Yogyakarta: Balai Arkeologi Yogyakarta.

dkk.1998. Penelitian Situs Sangiran: Eksistensi artefak pada Awal Kala Plestosen Tengah dan Stratigrafi Endapan Teras di Atas Seri Kabuh dan Seri Notopuro, Berita Penelitian Arkeologi No. 03. Yogyakarta: Balai Arkeologi Yogyakarta.

2002. The Pacitanian Culture: Who Owns It ?, Gunung Sewu in Prehistoric Times. Yogyakarta: Gadjah Mada University Press. 